Bот. GAZ. 132(3): 215-224. 1971.

\title{
STUDIES OF PALEOZOIC CALAMITEAN CONES: WEISSIA KENTUCKIENSE GEN. ET SP. NOV.
}

\author{
G. W. ROTHWELL AND T. N. TAYLOR
}

Department of Biological Sciences, University of Illinois at Chicago Circle, Chicago, Illinois 60680

\section{ABSTRACT}

The recent discovery of a new petrified fructification from the Lewis Creek coal ball locality in eastern Kentucky adds to our knowledge of the structure and diversity of calamitean cones. The incomplete specimen measures $4.8 \mathrm{~cm}$ long and $6.0 \mathrm{~mm}$ in diameter, and is composed of alternating bract and sporangiophore whorls. Approximately 24 bracts are present in each whorl. Bracts arise at right angles to the axis and are fused into a shallow disk for $2.0 \mathrm{~mm}$ before arching distally and becoming free. Six sporangiophores arise obliquely from slightly above each bract disk; each sporangiophore bears two large pendant sporangia that are attached along their distal and tangential surfaces. Sporangial walls are a single cell layer thick and are characterized by internal cell lumen partitions. The distal ends of the sporangiophores are fused to form a continuous ring of tissue that surrounds the sporangia. Features of the new cone are discussed in relation to those of other calamitean cones of similar age.

\section{Introduction}

The large number of calamitean cones described from the Carboniferous of Europe and equivalent strata in North America clearly demonstrates the diversity of structure within this group of plants during the latter portion of the Paleozoic. Compression specimens of these cones exhibit an extended range of features, including sporangiophores 
that arise immediately above, midway, or just below bract whorls. Sporangial number includes taxa containing one (Metacalamostachys [HIRMER 1927]); two (Calamostachys bisporangiata [Аввотт 1968], C. noei [DARRAH 1969]); or four (i.e., species of Palaeostachya) sporangia per sporangiophore. Structurally preserved calamitean cones illustrate an equally diverse range of sporangiophore positions; however, the number of sporangia per sporangiophore is either two or four. The large number of taxa with four sporangia (i.e., Calamostachys, Palaeostachya, Calamocarpon) demonstrates the diversity among cones of this type. Structurally preserved cones with two sporangia per sporangiophore are less completely known and limited to the middle Pennsylvanian species Mazostachys pendulata (KosAnke 1955). The present study describes another calamitean fructification bearing two sporangia and provides an opportunity to expand our knowledge of structurally preserved cones of this type.

The specimen described in this account was discovered in coal ball material collected at the Lewis Creek locality in eastern Kentucky (TAYLOR and STEWART 1964). The source of the Kentucky petrifactions is immediately below the Magoffin marine zone within the Breathitt Formation (HUdDLE et al. 1963) and presently occupies an uncertain age of either lower or middle Pennsylvanian. The composition of the known flora from this locality indicates a closer resemblance to the Westphalian A or equivalent strata of Europe (Good and TAYLOR 1970) and is therefore suggested as representing lower Pennsylvanian time according to North American terminology.

Initial sections of the coal ball exposed the specimen in slightly oblique transverse section and separated from a short section of the cone peduncle. Serial peels were made of approximately two whorls of sporangiophores prior to recutting and grinding the slab to expose the cone in longitudinal section. Cellulose acetate preparations were then made from the periphery of the cone to slightly beyond the median longitudinal plane of the axis; transverse sections were also prepared of approximately 5.0 $\mathrm{mm}$ of the penduncle before making longitudinal peels of that region.

\section{Systematics}

WEISSIA GEN. NOV.

Generic diagnosis.-Weissia gen. nov.: Cones constructed of alternating bract and sporangiophore whorls. Cone axis vascular system of superimposed bundles and secondary tissues. Bracts horizontally fused to form a disk, individual units free at cone margin. Sporangiophores inserted immediately above bracts at $45^{\circ}$ angle, distally bearing two sporangia; distal end of sporangiophores joined by narrow undulating ridge. Spores spherical and trilete. Type species: Weissia kentuckiense sp. nov.

SpeCIFIC DIAGNosis.-Weissia kentuckiense sp. nov.: Characters of the species those of the genus. Cones up to $6.0 \mathrm{~mm}$ in diameter and $4.8 \mathrm{~cm}$ long. Axis of parenchymatous pith surrounded by three pairs of endarch vascular bundles and continuous cylinder of secondary xylem with reticulate-circular simple pits. Bracts approximately 24 per whorl, vertically extending to sterile whorl above and characterized by undulating abaxial surface. Sporangiophores six per whorl with diamond-shaped stalks, and expanded, fused distal ends. Sporangia large $(2.3 \times 1.9 \times 0.8 \mathrm{~mm})$ and attached to sporangiophore along upper and outer surface; sporangium wall a single cell layer thick with prominent buttresses projecting across cell lumens. Spores psilate-granulose and ranging from 39 to $60 \mu$ in diameter. Vegetative parts unknown. Holotype: Slides and peels of the specimen in Coal Ball 2060 deposited in the Paleobotanical Collections, Department of Biological Sciences, University of Illinois at Chicago Circle. All permanent slides include acquisition numbers 2,389-2,585 in the above collections. Collection locality: Lewis Creek (4 miles east of Chappel townsite, Leslie County), Kentucky. Stratigraphic position: Copland Coal, Breathitt Formation. Age: Lower-middle Pennsylvanian. Etymology: The generic name Weissia is proposed in honor of C. E. Weiss for his contributions on calamitean fructifications. The specific name kentuckiense refers to the collection locality.

\section{Description}

General feAtures.-The incomplete cone measures $4.8 \mathrm{~cm}$ long and $6.0 \mathrm{~mm}$ in diameter (fig. 1), and is constructed of 34 whorls of alternating bracts and sporangiophores. The axis consists of a solid parenchymatous pith surrounded by six primary bundles, a continuous cylinder of secondary xylem, and a generally poorly preserved cortex (figs. 3,4$)$; primary vascular bundles do not alternate from node to node. Bract whorls are borne along the axis at intervals of $2.7 \mathrm{~mm}$ with the individual whorls consisting of approximately 24 bracts that are laterally fused to form a shallow disk. Near the periphery of the cone the bracts arch upward, separate, and partially cover the bract disk above. Three pairs of sporangiophores are inserted above each bract disk and extend from the axis at an angle of approximately $45^{\circ}$ (fig. 6). Distally each sporangiophore is expanded laterally and fused with the sporangiophore on either side by an undu- 

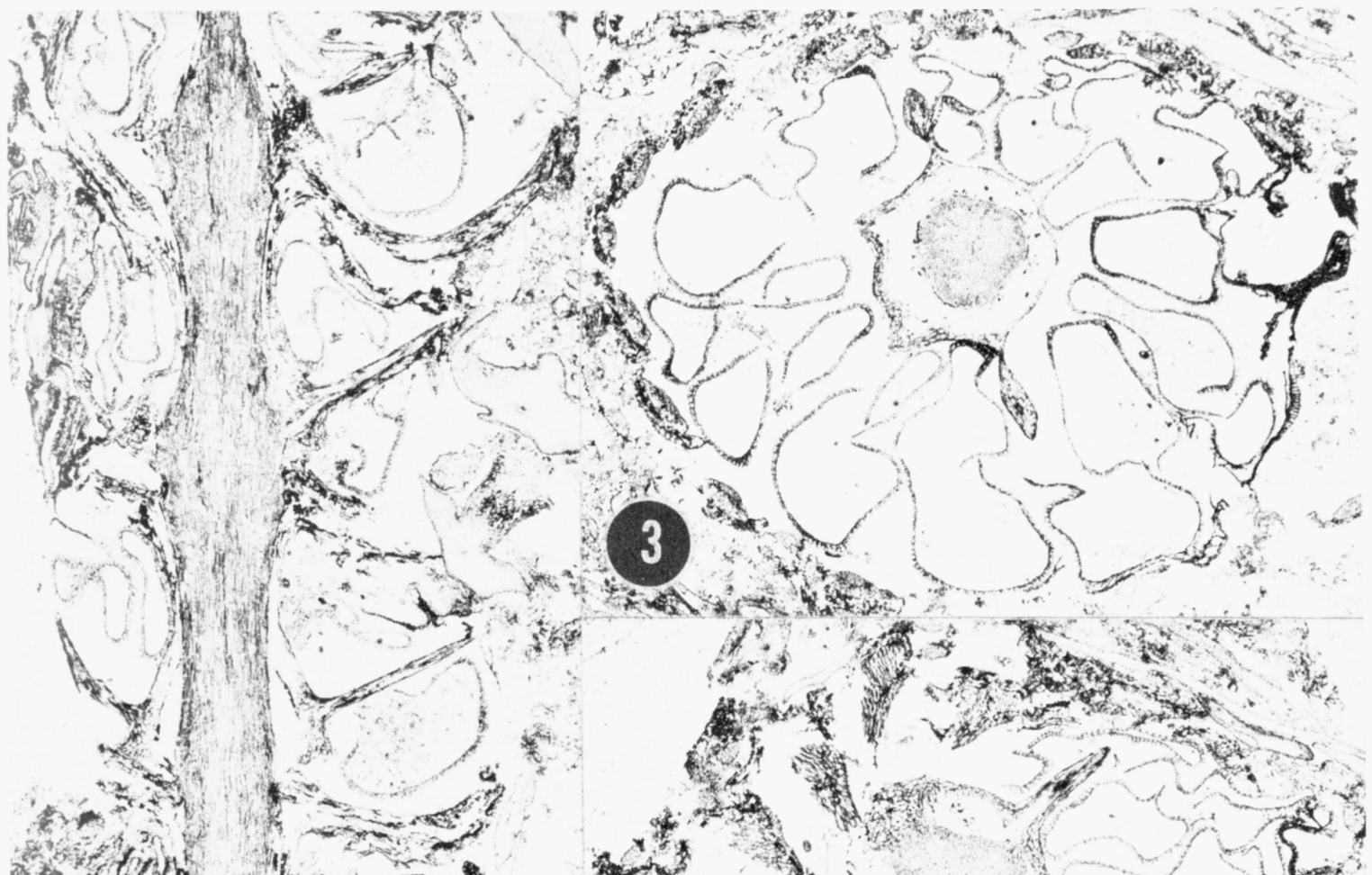

- fol

(4)

7
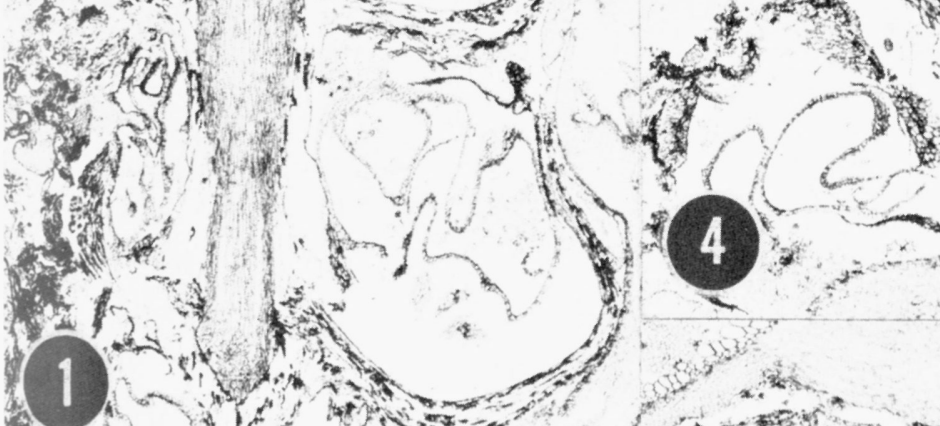

be$$
\text { \& }
$$ 


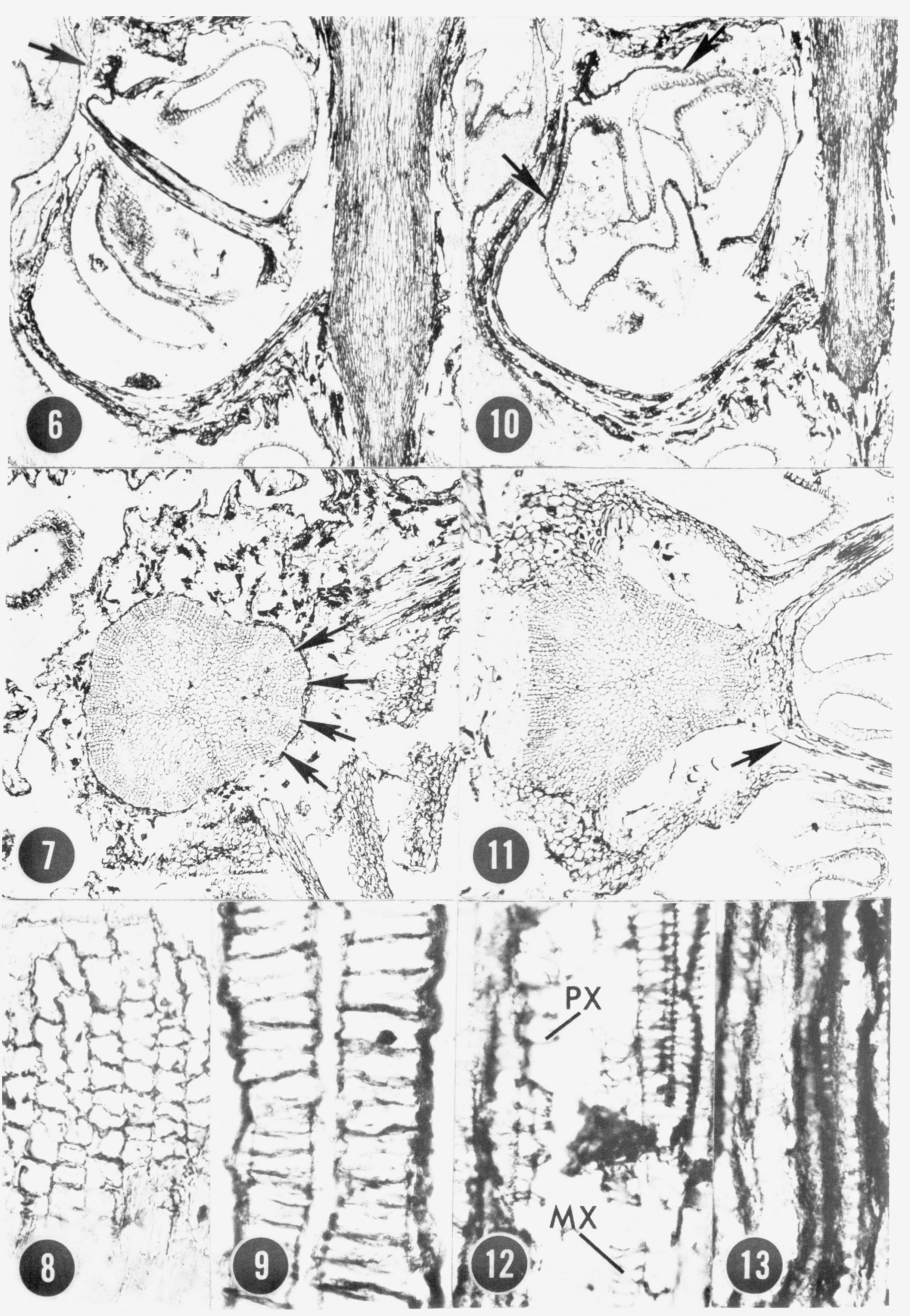


lating ridge of tissue. Two large pendant sporangia containing spores of the Calamospora type are attached to the distal end of each sporangiophore.

Axis.-The cone axis has a maximum diameter of $1.8 \mathrm{~mm}$ at the nodes with a decrease to approximately $1.2 \mathrm{~mm}$ recorded in the internodal regions above the sporangiophores. The central region of the axis contains a solid parenchymatous pith at both nodal and internodal regions (figs. 7, 11). Pith cells are elongated longitudinally, and in transverse section appear polygonal ranging from 6 to $40 \mu$ in diameter and up to $350 \mu$ long; end walls may be either transverse or oblique.

The primary vascular system consists of three pairs of bundles located at the periphery of the pith (fig. 11), and these are represented by carinal canals and associated metaxylem tracheids. Individual carinal canals measure approximately $40 \mu$ in diameter and typically show remnants of annular-spiral protoxylem elements near the margin (fig. 12). Metaxylem tracheids occur in one to two rows on the radial and tangential walls of the carinal canals; centripetal wood is characteristically absent. At the level of bract trace departure each carinal canal is interrupted by vascular elements that fill the canals at these points. Scalariform metaxylem tracheids (fig. 12) are roughly circular in transverse section and average approximately $12 \mu$ in diameter.

Sporangiophore and bract traces arise from the primary bundles at separate levels and pass directly into each structure. Individual traces depart at approximately right angles from the axial bundles and do not form gaps.

The major portion of the cone axis consists of a continuous cylinder of three to seven rows of radially aligned secondary xylem tracheids that are present at both the nodal and internodal regions (figs. $7,11)$. In transverse section individual vascular elements appear rectangular and average approximately $15 \mu$ in diameter. Secondary wall patterns range from reticulate to simple uniseriate circular pits (fig. 13).

The cortex of the cone axis is approximately 0.2 $\mathrm{mm}$ thick in the internodal regions and is construct- ed of poorly preserved elongate cells which are typically filled with amorphous materials. Similarly appearing cells have been reported in the cortex and ground tissues of both fertile and sterile calamitean material (HICK and CASH 1884; Hick 1893, 1894; Hickling 1910; Thomas 1912; ARNOLD 1958; TAYLOR 1967) and are referred to as components of a melasmatic tissue. In the nodal regions the cortex expands to an average thickness of $0.3 \mathrm{~mm}$ and is composed of thick-walled, isodiametric cells of variable size that lack internal contents. At the level of sporangiophore insertion, and between the arms of the stele, lacunae constitute the inner region of the cortex (figs. 4, 11). Similarly appearing lacunae have been reported in the cortical tissues of Calamostachys americana (ARNOLD 1958) and are considered a result of fossilization rather than an ontogenetic feature of the tissue system.

Peduncle.-A short section of the cone peduncle is preserved for approximately $1.5 \mathrm{~cm}$ below the saw kerf that separates it from the most proximal cone sections. In transverse section the anatomy of the peduncle is identical with that described for the cone base, with the exception that the peduncle exhibits seven primary vascular strands whereas six are present in the cone. The ground tissue of the peduncle is poorly preserved and measures approximately $0.2 \mathrm{~mm}$ in maximum thickness. In figure 2 a parenchymatous disk with an undulating margin can be seen surrounding the axis. This structure, which results from an expansion of the cortex, measures $0.6-1.2 \mathrm{~mm}$ thick, and is similar to structures described at the base of $C$. binneyana (Thomas 1909; Taylor 1967).

STERILE WHORL.- The number of bracts per whorl is variable; however, 24 is the most common number encountered. Bracts arise at right angles to the axis and are fused into a shallow disk for approximately $2.0 \mathrm{~mm}$ before arching upward and becoming free (fig. 5). Each bract extends vertically for $3.0-3.5 \mathrm{~mm}$ and overarches the bract disk base above (fig. 19). Figures 6 and 10 illustrate the undulating abaxial surface of the bract disk
Figs. 6-13.-Weissia kentuckiense gen. et sp. nov. ( $M X=$ metaxylem; $P X=$ protoxylem). Fig. 6, Longitudinal section showing disposition of bract and sporangiophore, and attachment of sporangium. Undulating ridge indicated by arrow; U.I.C.C. Coal Ball \#2060 C(2) side \#172; X 22. Fig. 7, Transverse section of cone axis at bract node showing departure of four traces (arrows); U.I.C.C. Coal Ball \#2060 C(2) bottom $\# 114 ; \times 37$. Fig. 8, Paradermal section of sporangium wall showing buttresses in vertically oriented wall cells; U.I.C.C. Coal Ball \#2060 C(2) bottom \#90; $\times 390$. Fig. 9, Transverse section of two sporangium walls showing disposition of buttresses; U.I.C.C. Coal Ball \#2060 C(2) side \#172; $\times 410$.
Fig. 10, Longitudinal section of cone showing attachment of one sporangium to distally expanded sporangiophore tissue (arrows); U.I.C.C. Coal Ball \#2060 C(2) side \#178; X 22. Fig. 11, Transverse section of cone axis at sporangiophore node showing attachment of two sporangiophores and departure of sporangiophore trace (arrow); U.I.C.C. Coal Ball $\# 2060 \mathrm{C}(2)$ bottom \#153; $\times 37$. Fig. 12, Longitudinal section of axial vascular bundle showing protoxylem and metaxylem tracheids; U.I.C.C. Coal Ball \#2060 C(2) side \#164; $\times 370$. Fig. 13, Longitudinal section of axis showing pitting of secondary xylem elements; U.I.C.C. Coal Ball \#2060 C(2) side $\# 164 ; \times 370$. 
that occurs near the point of attachment to the cone axis. In transverse section at the level of separation individual bracts are fusiform in outline (figs. 3, 17). Individual bracts measure up to $0.7 \mathrm{~mm}$ wide, and are composed of five distinct zones. Extending from the center of the bract to near the abaxial surface is a region of longitudinally elongate fiberlike cells. On the abaxial side of these cells is a zone one to two elements thick which is composed of thin-walled cells identical with and continuous with the melasmatic tissue of the axis. A flattened vascular strand of five to eight scalariform tracheids extends the length of the bract between these two tissue systems. A zone of thin-walled mesophyll cells surrounds the above tissues. This cell layer has its greatest development along the sides of the bract where it attains a thickness of up to eight cells. Along the abaxial surface this sheath of cells is reduced to two to four cell layers, and it is totally absent from the abaxial surface. Although a uniseriate epidermis can be identified on the bract surface, stomata were not observed in any of the preparations.

Twelve bract traces arise from the axis, two from each vascular bundle (fig. 7). Traces cannot be followed through the cortex of the axis; however, the number of bracts suggests that each trace undergoes a dichotomy resulting in a single vascular strand in each of the 24 sterile members.

SPORANGIOPHORES.- Six sporangiophores are inserted approximately $0.8 \mathrm{~mm}$ above each bract disk. This interval is determined by the distance between bract and sporangiophore trace departure points from the axial bundle. Each sporangiophore extends out from the axis at a $45^{\circ}$ angle for approximately $2.25 \mathrm{~mm}$ (fig. 6) and then expands laterally at the distal end to form a shallow saucer-shaped structure to which the sporangia are attached along the inner surface (figs. 10, 14, 19). Along the lateral surface of the sporangiophore head one can observe a continuity of tissue between adjacent sporangiophores (figs. 3-5, 15, 19). The most distal sporangiophore tissue forms a horizontally disposed ridge that is best illustrated in a series of tangential sections. In figure 14 the sporangiophore stalks $(S)$ are expanded to attach the sporangia (arrows). In this figure sections of the ridge are widely sepa- rated. In figure 15 the expanded tissue of adjacent sporangiophores is continuous (arrow), and sections of the ridge are closer together. In a plane farther out from the axis than that in figure 15 the continuity of the ridge tissue between the sporangiophores is easily observed (fig. 16). The difficulty in obtaining tangential sections of the ridge is the result of the uneven course of the structure along the surface of the sporangiophore head (fig. 19).

The fused sporangiophore tissue is composed of generally poorly preserved cells in the region of sporangial attachment (figs. 6, 10, 14-16). Tissue of the ridge appears aerenchymatous with numerous large lacunae (fig. 16) present throughout the structure. Extending over the surface of the ridge is a uniserinte epidermis constructed of thin-walled cells containing resinous-appearing contents (figs. 15, 16).

In transverse section the sporangiophore stalks exhibit a diamond-shaped configuration (fig. 3). Cells of the stalk ground tissue are elongate and tend to parallel the long axis of the structure (fig. 11). A terete vascular strand composed of four to nine scalariform tracheids extends out from the axis at right angles and traverses the sporangiophore stalk (fig. 11). No vascular elements could be identified in the expanded portion of the sporangiophore head.

Sporangia.- Two large $(2.3 \times 0.8 \times 1.9 \mathrm{~mm})$, pendant sporangia are attached to the distal end of each sporangiophore (fig. 19) along their upper and tangential surfaces. Sporangial walls are a single cell layer thick and range from 45 to $15 \mu$ in the tangential dimension. In figure 3 all of the sporangia appear broken at the approximate midpoint. It is along this line that the smallest sporangial cell walls were observed, and this suggests that these cells were involved in sporangial dehiscence. In section view sporangial cell walls are rectangular with the inner walls characterized by internal thickenings which have been referred to by other authors as buttresses (i.e., WiLliamson and Scott 1894; Kosanke 1955; TAylor 1967). An examination of these cells in face view indicates that the thickenings occur on the lateral walls of the cells and project across the entire length of the cell lumen (fig. 8). In transverse sections, made
Figs. 14-18.-Weissia kentuckiense gen. et sp. nov. $(R=$ ridge; $S=$ sporangiophore; $V B=$ vascular bundle). Fig. 14, Tangential section of cone showing sporangiophore stalks, expanded sporangiophore tissue (arrows) attaching sporangia, and sections of inflated distal ridge; U.I.C.C. Coal Ball \#2060 $\mathrm{C}(2)$ side $\# 254 ; \times 41$. Fig. 15 , Tangential section of cone slightly further from the axis than fig. 14 showing fused distal sporangiophore tissue (arrow); U.I.C.C. Coal Ball \#2060 C(2) side \#265; $\times 41$. Fig. 16, Tangential section of cone slightly further from axis than fig. 15 showing distal ridge of sporangiophore tissue; U.I.C.C. Coal Ball \#2060 C (2) side \#281; X 41 . Fig. 17, Transverse section of cone bract showing disposition of tissues; U.I.C.C. Coal Ball \#2060 C(2) bottom \#12; X 125. Fig. 18, Calamospora type spore from peel preparation; U.I.C.C. Coal Ball \#2060 C (2) bottom \#171; $\times 500$. 

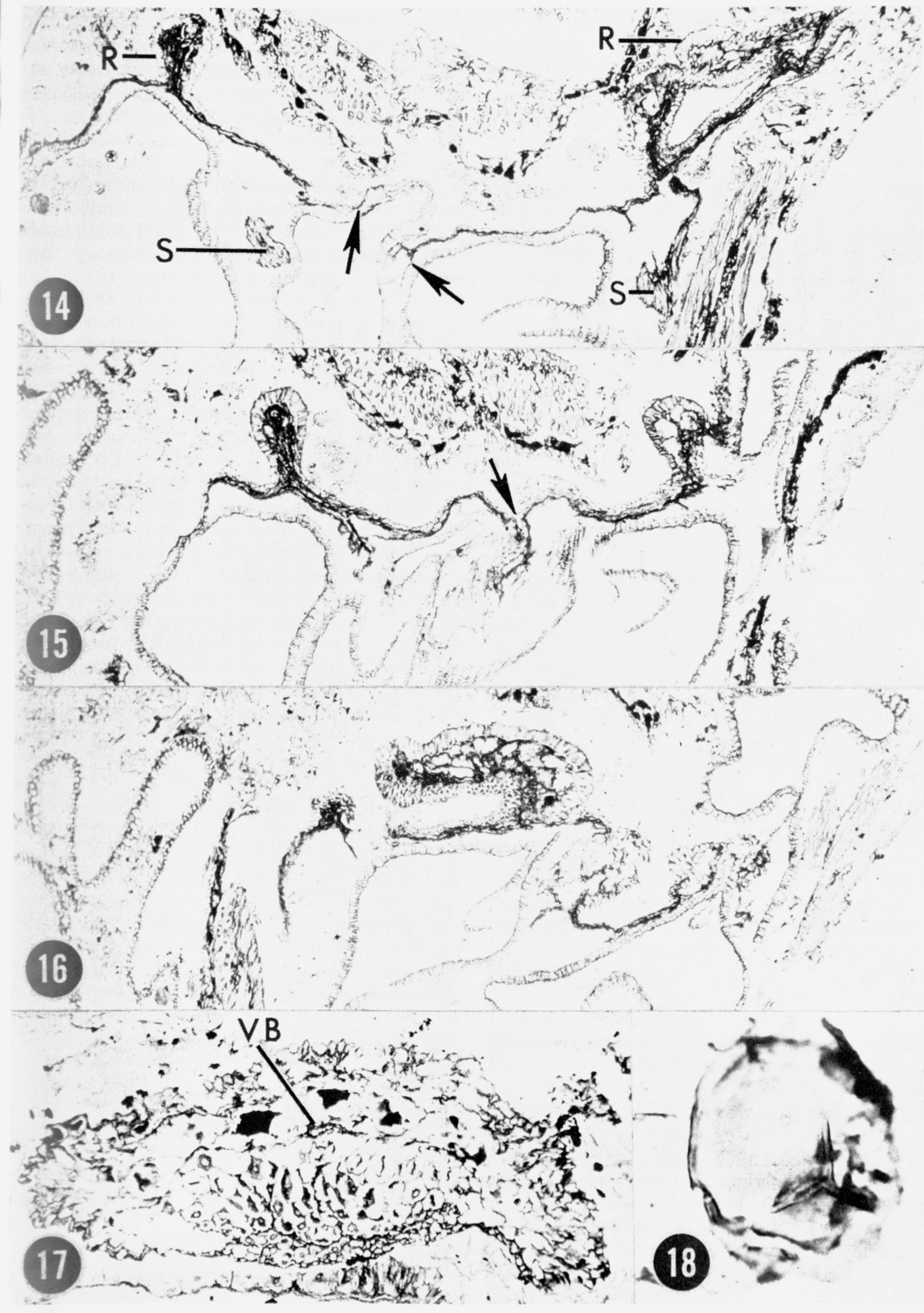


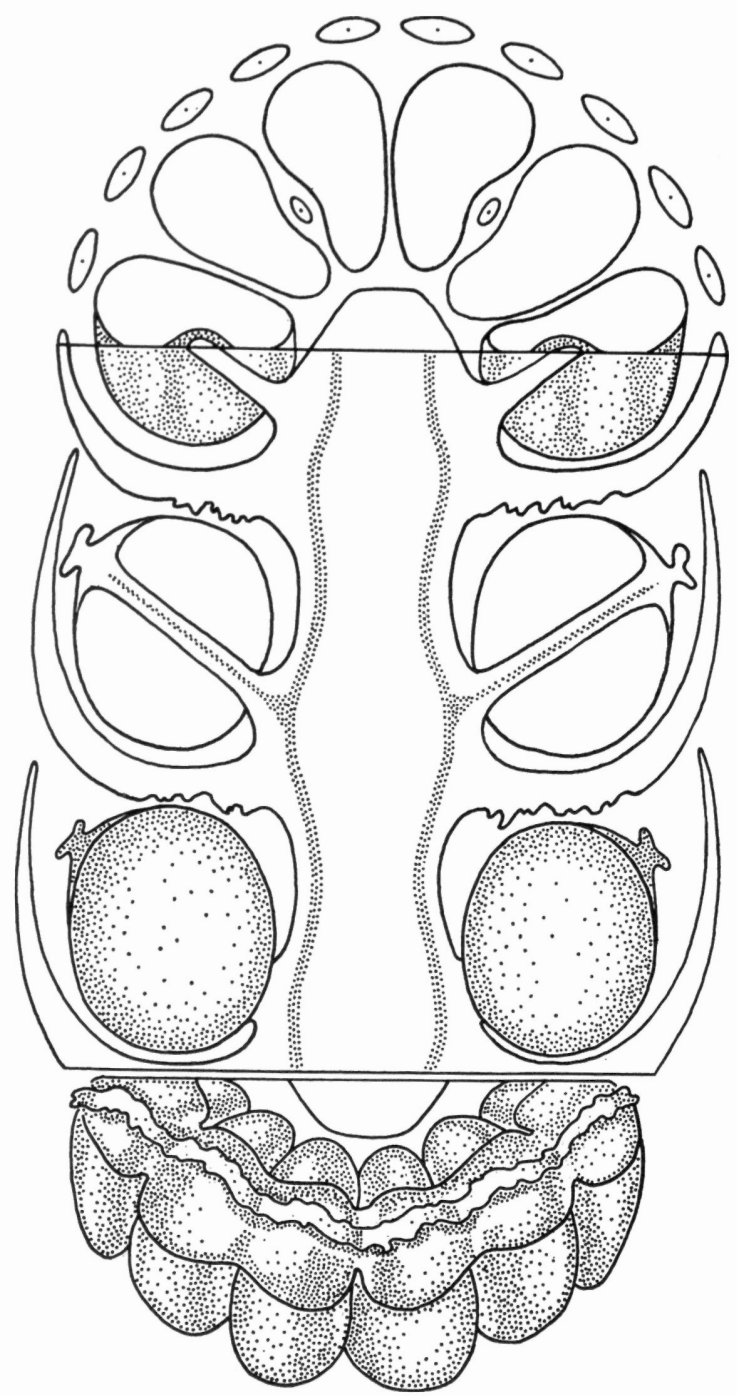

FIG. 19.--Suggested idealized reconstruction of Weissia kentuckiense. Upper segment illustrates transverse section at internode; middle segment illustrates median longitudinal section; lower segment illustrates sporangia attached by laterally expanded and fused sporangiophore tissue, and continuous inflated ridge of horizontally disposed sporangiophore tissue.

parallel to the long axis of the sporangial wall cells, these projections extend from the top to the bottom of the cell (fig. 9), indicating that they represent partitions similar to those described by WiLliamSON and SCOTT (1894) and Kosanke (1955), although in the latter instance partitions are less completely developed and do not completely subdivide the cell.

Spores.-Almost all of the sporangia had dehisced prior to fossilization. All observations regarding the spores were therefore made from spores within sporangia on cellulose acetate peel prepa- rations. The histogram illustrated in figure 20 was constructed from 250 spore measurements and shows a size range of 39-60 $\mu$. Individual spores are spherical, psilate-granulose, and trilete. The trilete mark is prominent with extended arms and conspicuous lips (fig. 18); no contact areas (areae contagionis) were observed. If found in the dispersed condition spores of Weissia would be included in the genus Calamospora as defined by Schopf, Wilson, and Bentall (1944).

\section{Discussion}

The most distinctive feature of the new cone is the fused nature of the sporangiophores of each fertile whorl. Laterally fused sporangiophores have not previously been reported as a feature of calamitean cones except for a possible similar organization that may have existed in Mazostachys pendulata (Kosanke 1955), where a mass of poorly preserved cells appears similar in position and histology to the cells of the ridge of Weissia. In $M$. pendulata a tissue occurs at the apex of each sporangium and is considered a proliferation of the sporangium wall. An examination of the type material of $M$. pendulata suggests that the mass of tissue is separated from the sporangium by the sporangiophore and is in fact probably the expanded distal region of each sporangiophore. Neither the sporangiophore nor the aerenchymatous tissue of each whorl is laterally fused in $M$. pendulata although

$80-$

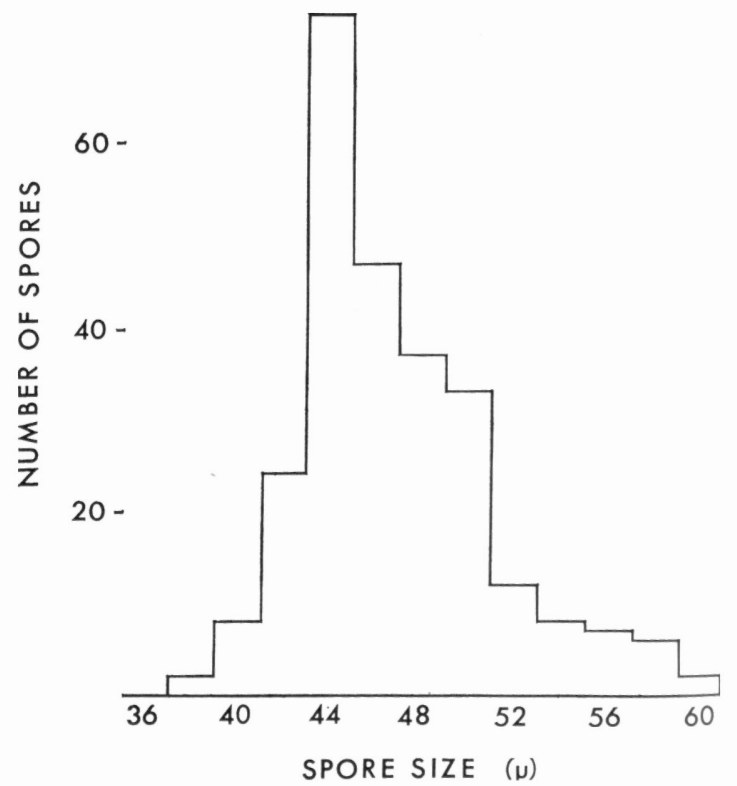

FIG. 20.-Histogram showing size-frequency of Weissia kentuckiense spores. 
some tissue remnants are present between the sporangiophores, and a coalified residue at the periphery of the cone may represent poorly preserved sporangiophore tissue.

Sporangiophores fused to one another in a fertile whorl may have served to protect the large, pendant, and otherwise easily crushed sporangia. The ridge of sporangiophore tissue that joins adjacent sporangiophore heads no doubt provided some structural support for the large sporangia during development. Other features of calamitean cones that may have served to protect developing sporangia include bracts fused in a shallow disk, imbricate whorls of bracts, and fleshy, enlarged sporangiophore heads which completely enclose axially directed sporangia.

Potential relationships among calamitean cones have been discussed by KosAnke (1955), who recognizes six structural types: pre-Calamostachys, Calamostachys, Palaeostachya, Cingularia, Metacalamostachys, and Mazostachys. The pre-Calamostachys form is characterized by the absence of bracts (i.e., Protocalamostachys [WALTon 1949]) and sporangiophores each bearing four sporangia. All known examples of this form are further distinguished by their occurrence in rocks of lower Carboniferous, or equivalent strata. Cones of the Calamostachys type are delimited by sporangiophores that arise midway between bract whorls, with each bearing four sporangia. Sporangiophores of the Palaeostachya type also bear four sporangia; however, these are inserted on the axis immediately above each bract whorl and are inclined at about a $45^{\circ}$ angle from the axis. Specimens of Cingularia contain sporangiophores each with four sporangia, each of which is pendant from the much flattened abaxial surface. When bracts are present they occur immediately above the fertile whorl. Cones of the Metacalamostachys type are easily distinguished by the presence of sporangiophores below each bract whorl, each bearing a single, large, sporangium. The Mazostachys-type cone has sporangiophores inserted below the sterile whorl; however, each sporangiophore terminates in two large sporangia.

On the basis of the number of sporangia per sporangiophore, Weissia appears most closely related structurally to Mazostachys. Additional similarities shared by these two fructifications include the number and arrangement of vascular bundles and sporangiophores, parenchymatous pith and secondary tissues, and large, pendant sporangia. On the basis of these characters one might conclude that Weissia is similar in enough features to warrant inclusion in the genus Mazostachys. However, it is our opinion that several features preclude this inclusion at the present time. Sporangiophores in Weissia are attached above each bract whorl at about a $45^{\circ}$ angle to the cone axis and are laterally expanded and fused at the distal end. Sporangial attachment occurs along the upper and outer surface, with the upper half of each sporangium enclosed by tissue of the sporangiophore. The disposition and arrangement of the sporangiophores in Mazostachys is significantly different, with the sporangiophores arising at right angles close to the base of the sterile whorl above. Moreover, sporangia are attached to the laterally expanded tissue of the sporangiophore stalk by a portion of their upper surface that is closest to the stalk. Last, although some aerenchyma tissue does occur in the region of the sporangiophore distal end in Mazostachys, there is presently no evidence to indicate that the sporangiophores are laterally fused.

Sporangiophore insertion in the Kentucky cone is similar to the organization present in cones of the Palaeostachya type. While Weissia may be interpreted as representing a level of sporangial reduction within the Palaeostachya line, similar to that postulated between Mazostachys and Metacalamostachys (KoSANKe 1955), it is our belief that the manner of attachment of sporangia is different enough to preclude such a relationship at this time.

As continued research with the Kentucky petrifaction material progresses, it is hoped that additional specimens of Weissia will be discovered attached to vegetative axes so that the natural affinities of the cone may be more accurately positioned.

\section{Acknowledgments}

The authors wish to acknowledge the Research Grants Committee of the Illinois State Academy of Science for providing funds to G. W. Rothwell, and the National Science Foundation for support to T. N. Taylor (GB-8749). We also would like to acknowledge the assistance of Dr. Russel A. PePPERS, Coal Section, Illinois State Geological Survey, for providing the type material of Mazostachys pendulata for comparison.

\section{LITERATURE CITED}

Аввотт, M. L. 1968. Lycopsid stems and roots and sphenopsid fructifications and stems from the upper Freeport coal of southeastern Ohio. Palaeontol. Amer. 6:1-25.
Arnold, C. A. 1958. Petrified cones of the genus Calamostachys from the Carboniferous of Illinois. Contrib. Mus. Paleontol. Univ. Michigan 14:149-165. 
Darrah, W. C. 1969. A critical review of the upper Pennsylvanian floras of eastern United States with notes on the Mazon Creek flora of Illinois. Darrah, Gettysburg College.

Good, C. W., and T. N. TAYLOR. 1970. On the structure of Cordaites felicis Benson from the lower Pennsylvanian of North America. Palaeontology 13:29-39.

Hick, T. 1893. Calamostachys binneyana (Schimp.) Yorkshire Geol. Polytechnic Soc., Proc. 12:279-293.

1894. On the primary structure of the stem in Calamites. Manchester Lit. Phil. Soc., Mem. Proc. 8:158-170.

Hick, T., and W. Cash. 1884. Contributions to the fossil flora of Halifax. 4. Yorkshire Geol. Polytechnic Soc., Proc. 8:370377.

Hickling, G. 1910. The anatomy of Calamostachys binneyana, Schimper. Manchester Lit. Phil. Soc., Mem. Proc. 54:1-15.

Hirmer, M. 1927. Handbuch der Paläobotanik. Oldenbourg, München und Berlin.

Huddle, J. W., E. J. Lyons, H. L. Smith, and J. C. Ferm. 1963. Coal reserves of eastern Kentucky. U.S. Geol. Survey Bull. 1120

Kosanke, R. M. 1955. Mazostachys-a new calamite fructification. Ill. Geol. Survey Rep. Invest. 180.
Schopf, J. M., L. R. Wilson, and R. Bentall. 1944. An annotated synopsis of Paleozoic fossil spores and the definition of generic groups. Ill. Geol. Survey Rep. Invest. 91.

TAYLOR, T. N. 1967. On the structure of Calamostachys binneyana from the lower Pennsylvanian of North America. Amer. J. Bot. 54:298-305.

TAylor, T. N., and W. N. Stewart. 1964. The Paleozoic seed Mitrospermum in American coal balls. Palaeontographica 115B:51-58.

Thomas, H. H. 1909. On the cone of Calamostachys binneyana (Carruthers) attached to a leafy shoot. New Phytol. 8:249253.

1912. On the leaves of Calamites (Calamocladus section). Roy. Soc. (London), Phil. Trans. 202:51-92.

Walton, J. 1949. On some Carboniferous Equisetineae from the Clyde area. I. Protocalamostachys arranensis gen. et sp. nov.- a hitherto undescribed type of strobilus. Roy. Soc. (Edinburgh), Trans. 61:729-736.

Williamson, W. C., and D. H. Scott. 1894. Further observations of the fossil plants of the Coal-measures. I. Calamites, Calamostachys, and Sphenophyllum. Roy. Soc. (London), Phil. Trans. $185: 863-959$. 